\title{
Building Autonomous Learners in English as a Foreign Language (EFL) Classroom
}

\author{
Abd. Rahman, Suharmoko \\ STAIN Sorong, Kota Sorong, Papua Bar. 98414, Papua, Indonesia \\ Corresponding e-mail: abdrahman28best@gmail.com
}

\begin{abstract}
The concept of learner autonomy has been widely discussed in the area of second language acquisition (SLA). Learner autonomy is the ability of the learners to take responsibility for their own learning. It is believed that this concept allows the learners to be more active and become effective language learners. However, more questions have arisen on how to implement this concept among learners. Therefore, this paper aims to explore some ways to implement the concept of learner autonomy in EFL classrooms. The writer promotes four main ideas that can assist the teachers to implement this concept in their EFL classroom as follows. Firstly, setting contextual and clear goals for learners and helping them to evaluate their clear contextual goals with guidelines for goal evaluation. Secondly, allowing learners to identify and maximize their preferred learning strategies. Thirdly, boosting learner's motivation intrinsically and extrinsically. Finally, adopting technology in learning and teaching.
\end{abstract}

Keywords: English as a Foreign Language (EFL), Second Language Acquisition (SLA), Autonomy

\section{INTRODUCTION}

Learners' autonomy has been proved to be powerfully related to many supportive factors such as high motivation, willingness to communicate, selfefficacy determining the success of language learning both in English as a second language (ESL) and in English as a Foreign Language (EFL) (Brown, 2007, Dickinson, 1995 \& Little, 1990). Autonomy itself is defined as a set of abilities which enable learners to direct their own learning, evaluate their learning activities and examine their learning output (Benson, 2003). Holec (1981) assumed that the ability and responsibility in practicing autonomy can be operated from five main areas namely setting the learning objectives, formulating content and material, choosing appropriate and suited methods and techniques, supervising procedures of learning and finally evaluating the whole learning process. However, in theory, implementing the concept of learner's autonomy will be easy, but it is more difficult in its application. Autonomy as the goal of any language classrooms results in questions on how to develop students' autonomy and how to make them able to apply this concept to their whole learning process especially in EFL classrooms. In EFL context, prescriptive curriculum, textbook-based learning and exam-based material, class size, different level of proficiency, and low motivation among learners have made the concept of autonomy more difficult to apply. Therefore, in this essay, I will try to promote some strategies which teachers can apply to build learner autonomy in an EFL context.

\section{PROMOTING LEARNER AUTONOMY}

\subsection{Providing Clear and Contextual Goals}

One way to promote autonomous learners is to set contextual and clear goals for students and help them to evaluate their clear contextual goals with guidelines for goal evaluation. The students must be actively involved in setting goals that correlate with both proficiency levels and interest. For instance, before the program starts, teachers and students discuss the specific goals of learning activities in the 
systematic ways. As the class has general goals mentioned in the curriculum, teachers and students can negotiate and relate the general goals provided by the curriculum to their own context such as their proficiency levels. The learning level will be very important for learner autonomy as if the goals is too low or too difficult, the students may feel overwhelmed and do not see any challenges needed to foster their self- learning.

In addition, the goals should be clearly defined with a good design plan and structured activities. Nunan (2003) suggested that one way to promote autonomy is providing clear instruction to the learners related to their learning goals. Nunan added that the involvement of the learners in designing the action plan to achieve their own goals is clearly needed to make their goals more explicit. It means that the students must be involved in determining suitable learning activities and in selecting the most suitable materials that can maximize their learning outcomes.

Additionally, personal goals as guidance should always be reviewed. The teachers can encourage their students to evaluate their personal goals to keep them focused and following their goals. Many ways and measurement of outcomes can help the students to do self- assessment on their goals such as through student profiles, learning journals, diaries and portfolios. Those records of measurement are able to provide students' learning records which show students' effort, progress and achievement needed for self-assessment. For example, in the first week the students are given opportunities to identify their learning needs and objectives and help them to make their own learning journals. This learning journal can be assessed in the halfway through or at the final term of the course. The self-assessment of the learning journal that they make regularly help students reflects on their own learning process.

\subsection{Finding the Best Learning Strategies}

Another way to promote autonomy is helping learners identify and maximize their preferred learning strategies. Elizando \& Garita (2013) stated that "how autonomous a learner becomes highly depends on how solid and effective strategies are" (p. 330). The importance of learning strategies should be discussed as many EFL teachers often focus more on how they teach than on how their students learn. Centralized curriculum and exam orientation in an EFL context brings the focus of the teacher more on what is the best way to teach and the best material in order to help their students pass the test. This will not enable students to develop their learning strategies which can make them more autonomous. Teachers should help students examine not only what material and activities are helping them to achieve the goal and be effective learners, but also what strategies and material that can maximize their learning process. Chamot, et. al (n.d) stated that learning strategies helped the students focus on how they learn rather than what is learned.

The concern on learning strategies can tackle numerous individual difficulties and needs of students in learning as the teacher provides the learners with tools which they can use to reach the learning goals. For example, instead of directly asking them about the task accomplishment, teachers can ask or identify the process or how their students finish the task. This activity encourages students to recognize their learning style so that they can develop their suited learning strategies. This helps them plan their future learning and do reflection independently in every task accomplished. Students with a selfknowledge of learning strategies are able to understand how to apply specific learning strategies for current tasks and apply them for future tasks. Oxford (1990) stated that developing students' awareness of the learning strategies significantly increase their possibility to be successful not only in relation to short-term goals but also in the long-term learning goals.

\subsection{Lifting Learners' Motivation}

Autonomous learning will only happen if the students are highly motivated. Jingnan (2011) stated that motivation is believed to be one of the determining factors in promoting learner autonomy. Jingnan added that students should have a strong desire regarded as an intrinsic motivation to take responsibility for their learning which is starting from formulating their objective, designing learning activities, selecting learning method, to assessing the learning processes. Thus, it is important for teachers particularly in EFL context to develop their students' motivation to enable them to activate their autonomous learning.

To accept the responsibility for their own learning, continue to develop their language skill and willingness to take part in the learning process, the students should be highly motivated. Sprat et al. (2002) assumed that motivation is a determining factor in promoting autonomous learners so before providing many activities to encourage autonomy in language learning, the teachers should ensure that their students have enough motivation driving them to engage and participate in all planned activities. For instance, in Indonesian EFL context, teachers generally find reluctant and unmotivated students and asking them to do self-learning will not be effective. However, when the teachers can develop their students' motivation especially their intrinsic motivation it is easier to activate their autonomous learning ability. 
Directing students to be autonomous learners means the application of varied activities inside and outside the classrooms, but when the students do not have any interest or desire to all the activities, the learning will be not effective and they will be more reluctant. Fitriani (Interview October 2016) reported that in her writing class she encouraged her students to do self-learning such as asking them to start writing their diary in English, but when she checked the students' work she found that only few students attempted the task. The students' unwillingness to follow the instruction in learning might be influenced by their low level of motivation. It also implies that promoting some activities encouraging students to be autonomous will not be effective as long as they do not have high motivation in learning. Therefore, before providing and directing autonomous activities for the learners, teachers should ensure that students have had a motivation driving them to do the learning and engage in the activities.

\subsection{Using Technology}

Finally, adopting technology in learning and teaching promotes autonomous learners. According to Schemenk (2005) "the popularity of learner autonomy may be at least partially related to the rise of computer technology and the growing importance of computers in language learning environments worldwide" (p. 107). As teachers, especially in EFL context, have a limitation on providing authentic material and limited hours of teaching, technologies can be the facilitator which enable students to access vast amounts of authentic material for self- directed learning and provides more learning opportunities outside the classroom. Thus, the use of technology can empower students to learn more independently because technology can develop their self-study and make them more responsible for their own learning. Kurtz (2012) stated that nowadays technologies have provided many beneficial tools and programs which enable learners to completely or partially get involved in their learning and are no longer limited by place and time.

Also, technologies can provide more opportunities for EFL learners to use the language in a meaningful situation. They can perform meaningful interaction with an authentic audience and the learning activities will be based on meaningful tasks. Therefore, teachers can encourage the students to take benefit from several types of technologies like computers, the internet, educational websites, digital teaching tools designed for students to practice on their own. Benson (2011) described that the development of technology-based language learning programs has resulted in more opportunities for the students to practice the target languages and it provides the amount of learning material needed to promote and foster learner autonomy. Using online websites, for example, can help students to control their own learning and they will have more choices and opportunities to practice their English skill. Another example, teachers can encourage students to use some websites to practice their writing such as writing blogs. Through Blogs students will have a chance to practice their writing skill comfortably without being embarrassed about making mistakes and students will have numerous opportunities to share their idea through writing.

\section{CONCLUSIONS}

To sum up, learners' autonomy is believed to help students maximize the learning outcomes as it develops students' awareness in determining their learning directions. Despite some difficulties in an EFL context such as prescriptive curriculum, textbook-based learning, exam-based material, and class size, the application of autonomy in foreign language learning is still very possible. Many strategies can be applied to promote autonomous learners such as providing clear and contextual goals, helping the student to find their best learning strategies, lifting their motivation and taking advantage of recent developments in technology. However, autonomy is not only about giving free choices to the students to choose what and how they learn something or transferring all control and responsibilities in learning to the learners but also it is about how to teach them to use their own capacity to learn effectively. It means that the teachers' role is still very important especially in facilitating this shifting process. Thus, these strategies introduced will be efficiently applied as long as the teachers give appropriate guidance and supervision

\section{REFERENCES}

Benson, P. (2003). Learner autonomy in the classroom. In Nunan, D. (Ed.) Practical English Language Teaching. New York: McGraw Hill.

Chamot, A. U., Keatley C., Foster C., Margaret, M., Gonglewski, Bartoshesky A. (n.d). Developing Autonomy in Language Learners Learning Strategies Instruction in Higher Education. National Capital Language Resource Center Georgetown University George Washington University; Center for Applied Linguistics. Retrieved from http://www.nclrc.org/guides/HED/pdfs/full.pdf

Dickinson, L. (1995). Autonomy and motivation: A literature review. System, 23, 165-74

Holec, H. (1981). Autonomy and Foreign Language Learning, Oxford: Pergamon Press. 
Jingnan, S. (2011). Autonomy in EFL Education. Canadian Social Science, 7, (5), 27-32.

Kurtz, L. M. (2012). Learning from Twenty-first Century Second Language Learners: A Case Study in Smartphone Use of Language Learners (Master thesis). Retrieved from http://lib.dr.iastate.edu

Little, D. (1990). Autonomy in Language Learning. London: CILT.

Nunan, D. (2003). Nine Steps to Learner Autonomy. Retrieved from http://www.andrasprak.su.se/polopoly_fs/1.84007.133 3707257!/menu/standard/file/2003_11_Nunan_eng.pd f.

Oxford, R. (1990). Language learning strategies: What every teacher should know. New York: Newbury House Publisher.

Schmenk, B. (2005). Globalising Learner Autonomy. TESOL Quarterly, 39(1), 107-118. 